\title{
Legal Protection for Patients Who Are Harmed as a Result of Wrong Diagnosis of the Doctor in the Service App-Based Health Online
}

\author{
Redyanto Sidi ${ }^{1}$, Suci Adha Aprilianti Sinaga ${ }^{2}$, Herlina Purba ${ }^{3}$, Trisna Murni ${ }^{4}$ \\ ${ }^{1}$ Lecturer Master of Laws Postgraduate Universitas Pembangunan Panca Budi \\ ${ }^{2,3,4}$ Students of the Master of Laws Postgraduate Universitas Pembangunan Panca Budi.
}

Corresponding Author: Redyanto Sidi

\begin{abstract}
Health service based online appear in the middle of the rapid development of technology and information. But in practice, in community service this raises the problem that the doctor was wrong in making a diagnosis of the patient. This research using the method of normative legal research with the approach of legislation (statue approach) using secondary data consisting of primary material, secondary legal materials and tertiary legal materials. The Data is then analyzed in the normative qualitative and prepared by the method of descriptive analysis that the obtained descriptions thoroughly and ends with a conclusion by using the deductive method as the answers from the problems that have been formulated. The results of this research showed that the health service-based online has been growing in Indonesia. This service is in great demand due to various advantages such as cheaper prices, flexible, wider range, and can improve health services. The implementation of application-based health service of the online organized by the Health Law governing health care. Then Permenkes 20 2019 set more on the health service-based online which is done through the application of health services. The legal protection given to patients who have experienced losses due to get the error diagnosis of the disease is done by a doctor can submit a complaint to MKDKI according to the provisions of Article 66 of the Law Practice of Medicine, in addition, the patient can also ask for damages suffered as a result of the use of health services is in accordance with the provisions UUPK namely
\end{abstract}

through the process of completion for nonlitgasi or in litigation.

Keywords: The Protection Of The Law, Patients, Health App-Based Online

\section{INTRODUCTION}

The development of an increasingly technological progress each day has helped human work in various fields of life. This progress has created many changes in society. Technology creates space and time as if there are no more lines between one individual with another individual to communicate or disseminate information through social networks on the internet. In addition, the development of infrastructure and the cheapness of the device to access the internet such as smartphones make people easy to find information about health services through the internet. With the ease in meeting the needs of the community to obtain a health service that can be done at anytime and anywhere without having to go to a Clinic, health center or Hospital, it encouraged the creation of various applications based health online providing services or consultation in the field of health.

Health services online or usually called with telemedicine is the organizer of health services conducted online by internet service as a means of supporting. Some of the service app-based health online has been widely used by the people of Indonesia as 
Halodoc, Alodokter, KlikDokter, Good Doctor, SehatQ. To use the app-the application of the first user downloading it through a computer or smartphone. Health service-based online very easy for people because it can be accessed anytime and anywhere without having to wait for the queue to receive a consultation from a doctor.

In the middle of the spread of the Corona Virus Disease 19 (Covid-19) the government more incentive to make various regulations to cope with the activities of the community, one of them with a campaign slogan of "stay at home" or stay home and some Government regulation that limits the Area of community activities will be the transmission of Covid-19 makes people not want to go to the Hospital for memeriksaa health conditions. These conditions become a factor preferred service app-based health online.

Although it gives a lot of advantages and ease, the service app-based health online also has its drawbacks and dangerous if not dealt wisely. The ease to access the internet can make anyone users can upload content and role to anyone in the health appbased online. It can harm the patient if not implemented wisely. For example, in the implementation of the health service-based online make the doctor can't check the state of the patient by the doctor in the application of health services resulting in the possibility of the presence of error or mistake in diagnosing patients who are feared will cause harm to the patient as a user of the user service app-based health online such.

In the service of conventional doctors, a doctor must have a Letter of Registration as a sign that the doctor is already competent in and have a Letter of Permission to Practice if practicing in a health facility or independent practice. This is one form of protection against patients as mandated in the Legislation of the Republic of Indonesia Number 29 Year 2004 on Medical Practice. In the Law Practice of Medicine, the location of the physician practice is restricted to only be on the 3 place practices. While the health service is online-based practices to be unlimited and can not be determined. Health service-based online raises the question of who will be responsible if the patient is harmed as a result of wrong diagnosis. Whether the issue be the responsibility of the healthcare provider based online or become the responsibility of a physician as an executor? Although during the pandemic Covid-19 service app-based health online there is a leeway but the protection and safety of patients remains to be seen.

\section{MATERIAL AND METHODS}

This research using the method of normative legal research that is by discussing the problem of the norm of which the habits of the norm or vague of norms with the approach of legislation (statue approach) of the laws and regulations in Indonesia. This study uses secondary data consisting of primary material derived from the laws and regulations related to service-based health line and secondary legal materials derived from the results of previous studies, the opinion of legal experts, articles related to health service-based online and tertiary legal materials. The Data is then analyzed in the normative qualitative. That begins with the collection of primary and secondary data then do data processing and clustering in order to obtain data that is simple so it is easy to be understood, Then the data have been compiled, analyzed with descriptive analysis method so that the obtained description thoroughly about legal protection for patients who are harmed as a result of wrong diagnosis of the doctor within the health service-based online and ended with the withdrawal of the conclusion with the use of the deductive method as the answers from the problems that have been formulated. 


\section{RESULTS AND DISCUSSION The Health Service Is Online-Based In Indonesia}

Technology has changed healthcare in the form of a consultation that was carried out in the conventional has an alternative, namely by using the servicebased health online (online). Health service-based online has been growing in Indonesia. This service is in great demand due to various advantages such as cheaper prices, flexible, wider range, and can improve health services. Trend consulting services health-based online increasingly in demand in the pandemic Covid-19 due to being an alternative for the community to still be able to obtain health care without having to meet face to face, directly to the hospital, so it can prevent the transmission of Covid-19. Health service-based online easier for the patient, because it does not need to stand in line for registration, in addition, patients can consult with doctors in other regions without a limited region or distance. The condition of Indonesia is an archipelagic country with service-based health online course can improve the equitable distribution of health care services, particularly for patients who are in remote areas. However, it requires a supporting infrastructure such as internet access is offered to obtain services based health online. Not only doctor in the country, patients can consult with doctors who are outside the country.

Health service-based online can be done directly (real time) in the form of a video call and call audio or can be done indirectly through the chat feature, comment in a website, or social media. With the video call feature of the patient can be face-to-face through the computer screen or smartphone. While in the service does not direct, the patient and the doctor does not have to be online at the same time (real time).

In the pandemic Covid-19, the implementation of service-based health online can be done by a doctor through the app or telemedisin as an Halodoc, Alodokter, KlikDokter, Good Doctor,
SehatQ with attention to effective communication. It is stipulated in Circular No. HK.02.01/menkes/303/2020 in which the organization of health services through the application telemedisin can be implemented during the Emergency Public Health and/or National Disaster Covid-19 to prevent the spread of Covid-19. But, according to Article 3 paragraph (2) and (4) the Regulations of Medical Council of Indonesia Number 74 Year 2020 about the Authority of the Clinical and Medical Practice via Telemedicine on the pandemic Corona Virus Disease 2019 (Covid-19) in Indonesia set that telemedisin is a service consultation or teleconsultation given by doctors and dentists to implement the principle of patient confidentiality and the practice of medicine through health servicebased online must have a certificate of Registration and license Practices in Health care Facilities (health care facilities) as with the provisions of the legislation.

Based on Article 7 of the Perkonsil Number 74 Year 2020, the practice of medicine in the health service-based online is obliged to make the medical record that can be specialized medical record conventional or electronic for each patient and stored in health care facilities. Perkonsil affirm the Regulation of the Minister of Health No. 20 of 2019 on the Implementation of the Services of Telemedicine among Health care Facilities that teleconsultation in Indonesia can only be done if it is integrated or cooperate with health care facilities.

\section{The Legal Regulation of Health Services Online-Based in Indonesia}

Health care is an effort to keep the health, cure disease and restore the health of the person, the family and the community where its implementation can be done independently or together through an organization. Health services conducted based on the intention of good to maintain, improve and treat the disease in the community. Health services are regulated in the Legislation of the Republic of 
Indonesia Number 36 Year 2009 on Health (Health Act) set forth in Article 1. Setting health services in the Health Legislation consists of the services of health promotive, preventive, curative, rehabilitative, and traditional.

According to Article 1 point 12 of the Law of Health explained that health promotion is an activity and/or a series of health care that prioritizes the activities that are health promotion. Preventive health services according to Article 1 number 13 Health Legislation is an activity prevention to response to a disease. Health care curative based on Article 1 of figure 14 of the Law of Health is headed and/or a series of activities the treatment is carried out for the healing of disease, the reduction of suffering due to illness, disease control, or control of the disability so that the patient's condition occurred as optimal as possible. Then what is meant by health services rehabilitative as in Article 1 number 15 of the Law of Health is a and/or series of activities to recover or restore the former patients into the community so that it can serve again as a member of society that is useful to himself and the community as much as possible according to his ability. While services health traditional explicitly set out in Article 1 of the 16 Laws of Health describes as a treatment and/or treatment with the means and drugs that draws on the experience and skills handed down empirically that can be accounted for and applied in accordance with the norms prevailing in the society.

In addition, organizers of health services should apply the principles in the implementation of a health service, namely the principle of legality, the principle of balance, the principle of transparency and the principle of justice.

The principle of legality the principle that each health service should be done based on the rules of the laws and regulations in Indonesia have permission health practices. The principle of the balance of the principle that health services provided can build public health a balanced, i.e. the balance between physical and mental health. The principle of openness in health care means that health services through the physician must provide information that is clearly related to the health condition of the patient so as to provide confidence to the patient. The last principle of justice, namely health services provide health services that are fair to all layers of the society at affordable cost.

The settings of the law application service-based health online implemented following the Regulation of the Minister of Health of the Republic of Indonesia No. 20 of 2019 on the Implementation of the Services of Telemedicine among Health care Facilities (Permenkes 20 2019). Based on Article 1 number 1 Permenkes 202019 what is meant by telemedicine is "the provision of health services remotely by health professionals with using information technology and communications, includes the exchange of information in the diagnosis, treatment, prevention of disease and injuries, research and evaluation, and continuing education of health care providers for the benefit of the improved health of individuals and communities." Then Article 2 Permenkes 202019 explain the services telemedicine "was implemented by the health workers who have a letter of permission in the practice of health care facilities Organizer.”

Under Article 3, paragraph (1) Permenkes 202019 there are several types of services telemedicine that teleradiology, telelektrokardiografi, teleultrasonografi, teleconsultation clinical, and consultation services telemedicine another in accordance with the development of science and technology. In the products of this law is also described that the supporting infrastructure in telemedicine is electricity and internet connection are adequate. Service-based health online is done in an application that can be downloaded through a computer or smartphone. Things that must be considered by the provider of the application i.e. the system security and data safety are adequate in the service app-based 
health online as mandated in Article 12 paragraph (1) Perkemenkes 202019.

In addition, based on Article 12 paragraph (2) and (3) Permenkes 202019 set that the application of telemedicine is provided by the Ministry of Health can be the provider of telemedicine, however given space also to be implemented telemedicine self along have been registered at the Ministry of Health. In the implementation of telemedicine as in Article 20 paragraph (1) Permenkes 202019 "the supervision and coaching conducted by the Ministry of Health, the Department of Health of the province and the Regional Office of the district/city.”

\section{Legal Protection for Patients Who Are Harmed as a Result of Wrong Diagnosis}

Doctors In The Health ServiceBased Online Legal protection is the right of every person to get the protection and equal treatment before the law and legislation, one of which is to get protection against patients in obtaining health services. In addition, the protection of the law is an attempt to provide protection to individuals with a balance between the overall rules with values that are manifested in the actions and attitudes to realize the order in the life of the community. Patient has the right to acquire the security and safety of himself during receive health care because patient safety is the law of the highest (agroti salus les suprema). The problem of patient safety related to the effectiveness of the implementation of service-based health online as a medical support are highly dependent on the standard operating procedure (SOP), standards and practices of the competence of the health consultation service online so that the organizers of the health service can provide the best health services to the public in a safe and quality.

The legal protection of the patient in the service app-based health online, in advance of the patient to know and understand the rights and obligations of a patient as mandated in Permenkes 202020. Article 18 paragraph (1) Permenkes 202020 mention some of the rights of the patient or recipient of health consultation is "a. answers to consultation and/or receive expertise according to the standard; $b$. receive the information is correct, clear and accountable, and honest about the results of the consultation and/or expertise," while the liabilities of the health consultation servicebased online consists of "a. send medical information in the form of picture, imaging, text, biosinyal, video and/or sound using electronic transmission according to quality standard to ask for answers to the consultation and/or acquire expertise; b. maintain the confidentiality of patient data; and c. provide information that is correct, clear, accountable, and honest about the results of the consultation and/or expertise to the patient."

Based on Article 9 of the Regulations of the Medical Council of Indonesia Number 74 Year 2020 about the Authority of the Clinical and Medical Practice via Telemedicine during The Corona Virus Disease 2019 (Covid-19) in Indonesia set up that there are some restrictions that should be avoided by doctors and dentists in implementing the medical practice with the concept of telemedicine or health service-based online ie "a. teleconsultation between medical personnel with the patient directly without going through the health care facilities; $b$. provide an explanation of dishonest, unethical, and not adequate to the patient or his family; c. diagnosis and management outside of its competence; d. ask investigations that are not relevant; e. perform despicable acts, acts of intimidation or acts of violence against patients in the implementation of medical practice; $\mathrm{f}$. perform the action invasive through teleconsultation; g. charge out rates set by the health care facilities; and/or provide a health certificate."

If the doctors are wrong and diagnosing the disease in the service appbased health online, causing a loss that is suffered by the patient or user, then the patient can make an effort in the form of 
complaints that are submitted to the Honorary council of Medical Discipline Indonesia. It has been implied specified in Article 66 of the Law of the Republic of Indonesia Number 29 of 2014 on the Practice of Medicine (the Law Practice of Medicine), which states that "Any person who knows or interests are impaired for the actions of a doctor or a dentist in running a medical practice can complain in writing to the chairman of the Honorary council of Medical Discipline Indonesia." The complaint is delivered to seek accountability doctor. According to the legal responsibility arising from the actions of a person who violates the ethical, moral and legal. Responsibility can also be interpreted as an obligation to feel a result by following the rules of the law of human consciousness related to the deeds done intentionally or unintentionally.

In addition to submitting a complaint against a doctor who one in determining the diagnosis to MKDKI, the doctor concerned can also be held legally responsible on the basis of an act against the law (onrechtmatige overheidsdaad) filed a lawsuit to the Court if in the process of implementation of service-based health online the doctors to provide consultation services that are not in accordance with his ability as prohibited in Article 9, letter c of the Regulation of the Indonesian Medical Council No. 74 by 2020.

In addition, under Article 39 paragraph (1) of the Indonesian Government Regulation No. 71 of 2019 on the Implementation of the System and Electronic Transactions, the organizers of the service app-based health online has an obligation to prevent any user or patient in order to avoid the loss which the operator must execute it with "prudence, security and integration of information technology systems, security control over the activities of the Electronic Transactions, the effectiveness and cost efficiency and consumer protection in accordance with the provisions of laws-invitation.”
In addition to the laws and regulations on top of the patient as a user of the service app-based health online also guaranteed rights as a consumer under Article 4 of the Law of the Republic of Indonesia Number 8 Year 1999 concerning Consumer Protection (Consumer Protection Laws). Based on Article 4 of the Law of Consumer Protection of the patient can ask for compensation in case of discomfort, issues of safety or losses incurred from the use of goods and/or services by the consumer (the patient). Fault diagnosis the doctor can be categorized as a violation of consumer rights as guaranteed in the Law of Consumer Protection so that these legal issues can be solved through the efforts of outside the court (an alterative dispute resolution) as mandated in Article 47 of the Law of Consumer Protection and through the efforts in the Courts (litigation) set forth in Article 48 of the Consumer Protection Act.

Based on Article 47 of the Consumer Protection Act, the patient as a consumer who felt harmed by the actions of doctors who misdiagnose in the health service-based online can pursue a settlement outside the court which was implemented to achieve peace with regard to the form and amount of compensation and/or for specific actions to guarantee it will not happen again or will not recur losses suffered by the patient. Settlement through non-litigation traveled can be through conciliation, mediation and arbitration.

While the settlement through the pengadilian Article 48 of the Consumer Protection Act explained that the court (litigation) can be taken by filing a lawsuit through the court referred to the provisions of the applicable laws with respect to Article 45 of the Consumer Protection Act. In addition, Article 46 of the Law of Consumer Protection has been providing four-way in filing a lawsuit to the court, that may be filed by a consumer (the patient) are harmed or beneficiary concerned (individual), a lawsuit filed by a group of consumers who have similar interests, 
Redyanto Sidi et.al. Legal protection for patients who are harmed as a result of wrong diagnosis of the doctor in the service app-based health online

consumer protection agencies, nongovernmental organizations, and government.

Thus patients who are harmed by the actions of a doctor who is wrong in doing the wrong diagnosis in the service appbased health online can accommodate the efforts of non-litigation through mediation, conciliation, and arbitration. While through the litigation of the patient can file a lawsuit to the court with due regard to the provisions of Article 45 and 46 of the Law on Consumer Protection.

\section{CONCLUSIONS}

Health service-based online has been growing in Indonesia. This service is in great demand due to various advantages such as cheaper prices, flexible, wider range, and can improve health services. The implementation of application-based health service of the online organized under the Laws of Health which regulates health services. Then Permenkes 202019 set more on the health service-based online which is done through the application of health services. The legal protection given to patients who have experienced losses due to get the error diagnosis of the disease is done by a doctor can submit a complaint to MKDKI according to the provisions of Article 66 of the Law Practice of Medicine, in addition, the patient can also ask for damages suffered as a result of the use of health services is in accordance with the provisions of the Consumer Protection Act, namely through the process of completion for non-litgasi (vide Article 47) or in litigation (vide Article 48).

\section{Acknowledgement: None}

\section{Conflict of Interest: None}

\section{Source of Funding: None}

\section{REFERENCE}

1. Badahura, Ilham. Penyalahgunaan Kewenangan Pihak Rumah Sakit Terhadap Pasien Di Tinjau Dari Sudut Hukum
Kesehatan. Journal Lex Et Societatis 1, no. 4. 2013.

2. Fachrezi, Faldi Biaggy, and Padmono Wibowo. Upaya Pemenuhan Hak Pelayanan Kesehatan Kepada Narapidana Di Lembaga Pemasyarakatan. Widya Yuridika: Jurnal Hukum 3, no. 2. 2020.

3. Frade, S., \& Rodrigues, H. Benefits, challenges and impact of teleconsultation a literature review. Studies in Health Technology and Informatics, 192, 1157. 2013.

4. Greenhalgh, T. Vijayaraghavan, S., Wherton, J., Shaw, S., Byrne, E., CampbellRichards, D., Bhattacharya, S., Hanson, P., Ramoutar, S., Gutteridge, C., \& others. Virtual online consultations: advantages and limitations. BMJ OPEN. 2019.

5. Hendrojono, Soewono. Batas Pertanggungjawaban Hukum Malpraktik Kedokteran dalam Transaksi Teurapeutik. PT. Srikandi, Surabaya. 2007.

6. Jonaedi Efendi dan Jognny Ibrahim. Metode Penelitian Hukum: Normatif dan Empiris. Prenada Media. 2018.

7. Karo Karo \& Pasaribu. Aspek Hukum Konsultasi Dokter melalui Media Online di Indonesia. Tadakulo Master Law Journal. 2019.

8. Kompas.com. Di masa PPKM Darurat, ini 5 Aplikasi Layanan Kesehatan Online. https://money.kompas.com/read/2021/07/09/ 200000926/di-masa-ppkm-darurat-ini-5aplikasi-layanan-kesehatanonline?page $=$ all, diakses pada Sabtu, 13 November 2021 pukul 15.17 WIB.

9. Koonin, L. M., Hoots, B., Tsang, C. A., Leroy, Z., Farris, K., Jolly, B., Antall, P., McCabe, B., Zelis, C. B. R., Tong, I., \& Harris, A. M. Trends in the Use of Telehealth During the Emergence of the Covid-19 Pandemic-United States, JanuaryMarch 2020. MMWR. Morbidity and Mortality Weekly Report, 69(43), 15951599. 2019.

10. Kusumawardani, Qurani Dewi. Perlindungan Hukum bagi Pengguna Internet terhadap Konten Web Umpan Klik di Media Online. Jurnal Penelitian Hukum De Jure 19, no. 1. 2019.

11. Mulana, Alfred, dan Ika Farmani. Platform Informatika Kesehatan Masyarakat Dalam Kasus Covid-19 di Bali. Jurnal Manajemen Informasi Kesehatan Indonesia 8, no. 2. 2020. 
Redyanto Sidi et.al. Legal protection for patients who are harmed as a result of wrong diagnosis of the doctor in the service app-based health online

12. Mulyana, Perlindungan Hukum Terhadap Perempuan dan Anak Akibat Tindak Pidana Abortus Provokatus Criminalis. Jurnal Wawasan Yuridika, 1(2). 2017.

13. Mustar, Maniso. Dokter Pustaka: Layanan Informasi Online Bidang Kesehatan Alumni Fakultas Kedokteran, Kesehatan Masyarakat dan Keperawatan Universitas Gadjah Mada Yogyakarta. Lentera Pustaka Jurnal Kajian Ilmu Perpustakaan, Informasi dan Kearsipan 5, no. 2. 2010, hlm. 97-108.

14. Novianto, W. T. Penafsiran Hukum Dalam Menentukan Unsur-Unsur Kelalaian Malpraktek Medik (Medical Malpractice). Yustisia Jurnal Hukum, 92(2). 2015.

15. Nurul Fibrianti. Perlindungan Konsumen dalam Penyelesaian Sengketa Konsumen Melalui Jalur Litigasi. Jurnal Hukum Acara Perdata Adhaper, Vol. 1, No.1. 2015.

16. Peraturan Konsil Kedokteran Indonesia No. 74 Tahun 2020 tentang Kewenangan Klinis dan Praktik Kedokteran Melalui Telemedicine Pada Masa Corona Virus Disease 2019 (Covid-19) di Indonesia.

17. Peraturan Menteri Kesehatan No. 20 Tahun 2019 tentang Penyelenggaraan Pelayanan Telemedicine Antar Fasilitas Pelayanan Kesehatan.

18. Peraturan Pemerintah No. 71 Tahun 2019 tentang Penyelenggaraan Sistem Dan Transaksi Elektronik.

19. Rani Tiyas Budiyanti. Perlindungan Hukum Pasien Dalam Layanan Konsultasi Kesehatan Online. Jurnal Hukum Kesehatan Indonesia. 2021.

20. Renaldo, Joshua. Pengaturan Standar Atas Produk Rokok Sebagai Wujud Implementasi Undang-Undang Perlindungan Konsumen.
Jurnal Education and Development 8, no. 2. 2020.

21. Sitompul, A., \& Sitompul, M. N. (2020, February). The Combination Of Money Laundering Crime With The Origin Of Narkotics Crime To Islamic Law. In Proceeding International Seminar of Islamic Studies (Vol. 1, No. 1, pp. 671-681).

22. Tumiwa, Rendy, Sofia Pangemanan dan Effendy Sondakh. Efektivitas Kualitas Pelayanan Kesehatan Masyarakat pada Puskesmas di Kecamatan Dumoga. Jurnal Eksekutif 1, no. 1. 2018.

23. Undang-Undang No. 29 Tahun 2014 tentang Praktik Kedokteran

24. Undang-Undang No. 36 Tahun 2009 tentang Kesehatan

25. Undang-Undang No. 8 Tahun 1999 tentan Perlindungan Konsumen

26. Uscher-Pines, L., Mulcahy, A., Cowling, D., Hunter, G., Burns, R., \& Mehrotra, A. Access and quality of care in direct-toconsumer telemedicine. Telemedicine and E-Health, 22(4), 282-287. https://doi.org/10.1089/tmj.2015.0079.

27. Wahyudi, Setya. Tanggung Jawab Rumah Sakit Terhadap Kerugian Akibat Kelalaian Tenaga Kesehatan Dan Implikasinya. Jurnal Dinamika Hukum 11, no. 3. 2011.

How to cite this article: Redyanto Sidi, Suci Adha Aprilianti Sinaga, Herlina Purba et.al. Legal protection for patients who are harmed as a result of wrong diagnosis of the doctor in the service app-based health online. International Journal of Research and Review. 2021; 8(12): 159-166. DOI: https://doi.org/10.52403/ijrr. 20211221 